INTERNATIONAL JOURNAL OF RESEARCHES IN BIOSCIENCES, AGRICULTURE AND TECHNOLOGY (C) VISHWASHANTI MULTIPURPOSE SOCIETY (Global Peace Multipurpose Society) R. No. MH-659/13(N) wWw.vmsindia.org

\title{
FUNGAL DIVERSITY IN FRUITS
}

\author{
P. N. Nasare \\ Department of Botany, Nilkanthrao Shinde Science and Arts College Bhadrawati, Dist - Chandrapur (MS) \\ praveenkumarnasare@gmail.com
}

\begin{abstract}
:
The present work was carried out on fruits to study fungal diversity. The fruits were purchased and collected from Budhwar Bazar, Sakkardara Chauk, Nagpur and allowed to grow fungus on them. Among these collected 19 fruits those infected by fungus were identified as Humicola sp. (Pyrus malus L.); Mucor sp. (Psidium guajava L.); Fusarium sp.( Carica papaya L.); Aspergillus niger (Punica granatum L.); Mucor sp. (Syzygium cumunii (Linn.) Skeels; Aspergillus sp. (Vitis vinifera L.); Aspergillus niger (Citrulus lanatus L.); Aureobasidium sp. (Annona squamosa L.); Aspergillus flavus (Phoenix dactylifera L.); Aspergillus sp. (Aegle marmelos (Linn.) Corr; Fusarium sp. (Pyrus communis); Penicillium sp. (Cucumis melon L.); Aspergillus sp. (Emblica officinalis Garetn); Mucor sp. (Cocos nucifera L.); Aspergillus sp. (Lumonia acidissima Linn.); Fusarium sp. (Citrus indica L.); Trichoderma sp. (Citrus reticulata Syn L.); Fusarium sp. (Carissa carandus L.); Aspergillus sp. (Manilkara zapota L.) respectively. This shows that there is a great fungal diversity in fruits.
\end{abstract}

Keywords: Fungal diversity, fruits, Budhwar Bazar, Nagpur.

\section{Introduction:}

Fungi is the plural of the word fungus which is derived from the Latin word FUNGOUR which means to fluorish. The fungi may be defined as non-green, nucleated thallophytes . However, mycologists have defined fungi more scientifically. According to Alexopoulos (1962), the fungi include nucleated spore bearing achlorophyllous organisms that generally reproduce and whose filamentous branched somatic structures are typically surrounded by cell walls containing cellulose or chitin or both. A more technical definition of fungi was later given by Bessey (1968) which says that fungi are chlorophyll-less non-vascular plants whose reproductive or vegetative structures do not permit them to be assigned to positions among recognized groups of higher plants or algae. Fungi grow in diverse habitats. Majority of fungi prefer to grow in darkness and dim light in most habitat (Vashishta and Sinha, 2002).

\section{Materials and Methods:}

The fruit samples were purchased and collected from Budhwar Bazar, Sakkardara Chowk, Nagpur and fruits were allowed to grow fungi on them. For the identification of fungi, temporary slides were prepared by using cotton blue prepared in lactophenol is used as staining material for staining fungi. The temporary slides were prepared by scrapping small fragments of infected portion and sealed with paraffin wax and observed under Olympus light microscope. On the basis of morphological and reproductive characters, fungi were identified. For this, standard literature was used and experts opinion was taken.

\section{Results and Discussions:}

The infected fruits were observed to study fungal diversity and on basis of characters shown by different fungi, they were identified as follows. The observations, so observed are described in following paragraphs.

When fruits like Watermelon (Citrullus lanatus L.) and Pomegranate (Punica granatum L.) were collected along with the fungus, and when the fungus was observed under the microscope, it was found to be Aspergillus niger. While in Kavath (Limonia acidissima Linn).; Bel (Aegle marmalos (Linn) Corr.); Awala (Emblica officinnalis Gaertn), it was found to be Aspergillus spp.

Similarly, when papaya (Carica papaya L.), pear (Pyrus communis L.) and Lemon (Citrus indica L.); Karvand (Carissa carandas L.), it was found to be Fusarium spp. In Datepalm (Phoenix dactylifera L.), it was found to be Aspergillus flavus.

In Apple (Pyrus malus L.), it was found to be Humicola spp. In Jambhul (Syzygium cumunii (Linn) Skeels), it was found to be Mucor spp. In Coconut (Cocos nucifera L.) it was found to be Mucor spp. In Guava (Psidium guajava L.), it was found to be Mucor spp. In Custard apple (Annona squamosa L.), it was found to be Aureobasidium spp.

In Muskmelon (Cucumis melon L.), it was found to be Penicillium spp. In Orange (Citrus reticulata L.), it was found to be Trichoderma spp. In Chikoo(Manilkara zapota L.), it was found to be Aspergillus spp. In Grape (Vitis vinifera L.), it was found to be Aspergillus spp.

Earlier studies indicate that some of the

pathogens have been reported from different parts of India, either on the same or other host. Study on pathogenic fungi of fruits and vegetables was carried out by Dandge (1998). 
Shikha Agblor and Doug Waterer (2001) reported post harvest diseases in cabbage, caused by Botrytis and Sclerotinia. Chatage and Bhale (2010) reported Alternaria pluriseptata and Geotrichum candidus on ivy gourd (Coccinia indica).

Churde et al. (2011) reported Alternaria alternata, Phoma nebulosa, Curvularia lunata, Colletotrichum capsic,Curvularea senegalensis, Fusarium equiseti etc. on Brassica oleracea var. capitata L., Spinacea oleracea L.,Abelmoschus esculentus L., Capsicum annum L., Dolicus lablab L., and Solanum tuberosum L. respectively.

Exposure and / or consumption of such infected vegetables may cause health hazards (Bauri 2007).Hence, there is a need to explore possibilities of their control to prevent loss of product and injuries to human health.

According to Tournas (2005) after harvest, vegetables are often spoiled by a wide variety of microorganisms including many bacterial and fungal species. Fungi commonly causing spoilage of fresh vegetables are Botrytis cinerea, various species of the genera Alternaria, Aspergillus, Cladosporium, Colletotrichum, Phomopsis, Fusarium, Penicillum, Phoma, Phytophthora Pythium and Rhizopus spp. Botrytis cinerea,Ceratocystis fimbriata,Rhizoctonia solani, Sclerotinia sclerotiorum and some mildews. A few of this organism show a substrate preference whereas other such as Botrytis cinerea, Colletotrichum, Alternaria, Caldosporium Phytophthora and Rhizopus spp. affect a wide variety of vegetables causing devasting losses.

According to Sekhon and Shivapuri (1971), a number of fungi were found associated with stored cauliflower, common bean and pea seeds, but only Helminthosporium spp. on cauliflower, Fusarium sp. on common bean and Alternaria $s p$. on pea were proved to be pathogenic.

According to Wiley (1994), fungi are the third group of microorganis $m$ that affect the quality of fruits and make them unpalatable .These organism can be divided further into several categories but mould and yeasts are of the greatest concern in foods. The fungi are capable of independent life. The moulds and yeast are much more tolerant of acidity and reduced moisture. Moulds and yeast are the fungi of primary concern in fruits. It is conceivable that almost any microorganism might be found on a given fruits in a specific circumstances.

When Ann et al. (2004) inoculated Litchi (Litchi chinensis (Gaertn). Sonn on PDA medium at $8.32{ }^{\circ} \mathrm{C}$, with optimum growth at $28{ }^{\circ} \mathrm{C}$. They produced abundant conidia of Colletotrichum glaeosporioides on PDA plates at $24{ }^{\circ} \mathrm{C}$.

Fungi responsible for the spoilage of some berry, namely pawpaw (Carica papaya), sweet orange (Citrus sinensis), banana (Musa acuminata), garden egg (Solanum melongena),Lemon (Citrus limoni), and tangelo (Citrus tangelo). Fungi isolated include the genera of Aspergillus, Penicillium, Rhizopus, Articulopsora, Gonatobotryum, Varicosporium, Trichoderma,

Blastomyces,Fusarium,Pleurothecium and Yeast, Saccharomyces (Akinyele and Akinkunmi, 2012).

According to Akinyele and Akinkunmi (2012), the fungi found to be associated with the spoilage of pawpaw were A.niger, A.fumigatus, A.inflata, G.apiculatum, V.elodea, P.italicum; the fungi found to be associated with the spoilage of sweet orange were A.niger, A.inflata, P.italicum, B.dermatitidis, T. vivide, S.cerevisiae; the fungi grown on banana were A.fumigatus, P.chrysogenum, F. oxysporum; the fungi grown on garden egg were A.flavus,R.stolonifer, the fungi grown on lemon were A.niger, A.flavus, P.italicum, T. viride; the fungi grown on Tangelo were P.recurvatum,B.dermatitidis, S.cerevisiae.

According to Al-Hindi et al. (2011), the fungi grown on banana and grapes was Fusarium oxysporum, the fungi grown on Pokara and apricot was Aspergillus japonicus, fungi grown on orange was Aspergillus oryzae, fungi grown on lemon was Aspergillus awamori, fungi grown on tomato was Aspergillus phoenicis, fungi grown on peach was Aspergillus tubingensis, fungi grown on apple was Aspergillus niger, fungi grown on mango was Aspergillus flavus, fungi grown on kiwi was Aspergillus foetidus, fungi grown on date was Rhizopus stolonifer.

A.niger is a fungus commonly found on grapes (Chuze et al.,2006), apples (Oelofse et al., 2006) and tomatoes (Yildz and Baysal,2006). Okereke et al. (2010) reported that the fungi spp. isolated from the infected mangoes were A.niger,Alternaria sp., Botryodiolodia theobromae and Colletotrichum gloeosporioides.

Fusarium equiseti, A.flavus and A.niger grown on tomato fruits (Olaridan and Iwu, 1993). A.flavus and A.fumigatus grow on tomato (Adisa, 1993), peach and orange were infected by a no. of Aspergillus spp., A.niger, A. nidulans, A.variecolour, A.fumigatus, A.candidus (Sinha, 1946).

It is reported that Erysiphe cichoracearum grow on cucumbers, endive, lettuce, melons, potato, pumpkin, squash. 
Erysiphe cruciferarum grow on broccoli, Brussels sprouts, cauliflower and other cale crops; radiccio, radishes, turnips. Erysiphe pisi grow on peas. Erysiphe heraclei grow on carrots, parsley,parsnips. Erysiphe polygoni grow on beets. Leveillula taurica grow on artichoke, egg plant, peppers, tomatillo, tomatoes.

Spharotheca fuliginea grow on beans, black-eyed peas, cucurbits, okra (Powdery Mildew on Vegetables Management GuidelinesUCIPM, 2012). The fungi grown on Lettuce were Alternaria sonchi (Alternaria leaf spot), Michrodochium ponattonianum $=$ Marssinina panattonana (Anthracnose), Rhizyoctomia solani/ Thanatephorus cucumeris (telemorph) (Bottom rot), Cercospora longissima (Cercospora leaf spot),Pythium spp./ Pythium ultimum (Damping-off, Pythium), Rhizoctonia solani (Damping-off-Rhizoctonia), Bremia lactucae (Downy mildew), Sclerotinia sclerotiorum (Drop Sclerotinia rot), Botrytis cinerea (Gray mold), Phymatotrichopsis omnivora (phymatotrichum root rot), Erysiphe cichoracearum (Powdery mildew), Puccinia dioicae (Rust), Septoria lactucae (Septoria leaf spot),Sclerotium rolfsii (Southern blight), Stemphylium botryosum (stemphylium leaf spot), Pythium tracheiphilum (Wilt and leaf blight).

According to Morton (1987), the guava crop (mainly from wild trees) may be ruined by the uncontrollable fungus, Glomerella cingulata. $80 \%$ of the mature green fruits may be ruined by Mucor hiemalis. During rainy season, the fungus Phytophthora parasitica is responsible for much infectious fruit rot. Botryodiplodia spp., Dothiorella spp., Macrophomina spp. and
Gliocladium roesum grow on guava fruit. Colletotrichum gloeosporioides (Anthracnose) may attack the fruits in rainy season. Pestalolia psidii sometimes cause canker on green guavas.

It is reported that the fungi grown on strawberry were Botrytis cinera, Phytophthora cactorum, and Colletotrichum ocutatum (UCONN IPM Strawberry Diseases).

It is reported that the fungi grown on mango were Fusarium mangiferae (Britz et al., 2002); Fusarium sterilihyphosum (Marasas et al., 2006), Fusarium pseudocircinatum, Fusarium mexicanum (Otero-colina et al., 2012). Morsy et al. (2009) reported that Fusarium oxysporum, Fusarium solani, Sclerotium rolfsii, Rhyzoctonia solani, Macrophomina phaseolina cause damping-off to cucumber.

Different workers have reported various fungi from mango viz., Colletotrichum gloeosporioides (Rawal, 1998;. Savant and Raut, 2000; Ploetz et al., 1996; Sharma, 1993), P.mangiferae, Phoma spp. and Fusarium solani (Sharma, 1993; Sarvottam et al.,2009), as a cause of decline in quality of mango. P.mangiferae (Henn), Steyaeet (Synonym Pestalotia mangiferae Henn) causes grey blight of leaves (Verma et al., 1991), grey leaf spots, stem end rots, brown spots or rots of mango fruits (Mordue, 1980).

Babu et al., (2008) reported that Fusarium wilt on brinjal crop is due to the species Fusarium solani.Waller (1992) proposed that Colletotrichum musae (Berk and Curt) causes anthracnose in banana fruit and is confined to mature fruits.

The infected fruits were observed for fungal diversity and identified as follows-

Table 3:- Fungi identified on fruits of Bhadrawati and Warora Market.

\begin{tabular}{|l|l|l|}
\hline Sr.No. & Name of fruits & Fungus identified on fruits \\
\hline 1 & Pyrus malus L. & Humicola spp. \\
\hline 2 & Psidium guajava L. & Mucor spp. \\
\hline 3 & Carica papaya L. & Fusarium spp. \\
\hline 4 & Punica granatum L. & Aspergillus niger \\
\hline 5 & Syzygium cumunii (Linn.) Skeels & Mucor spp. \\
\hline 6 & Vitis vinfera L. & Aspergillus spp. \\
\hline 7 & Citrullus lanatus L. & Aspergillus niger \\
\hline 8 & Annona squamosa L. & Aureobasidium spp. \\
\hline 9 & Phoenix dactylifera L. & Aspergillus flavus \\
\hline 10 & Aegle marmolos (Linn) Corr. & Aspergillus spp. \\
\hline 11 & Pyrus communis L. & Fusarium spp. \\
\hline 12 & Cucumis melon L. & Penicillium $s p p$. \\
\hline 13 & Emblica officinalis Garetn & Aspergillus spp. \\
\hline 14 & Cocos nucifera L. & Mucor spp. \\
\hline 15 & Limonia acidissima Linn & Aspergillus $s p p$. \\
\hline 16 & Citrus indica L. & Fusarium $s p p$. \\
\hline 17 & Citrus reticulata Syn. L. & Trichoderma spp. \\
\hline 18 & Carissa carandas L. & Fusarium spp. \\
\hline 19 & Manilkara zapota L. & Aspergillus spp. \\
\hline
\end{tabular}




\section{Conclusion:}

It is concluded that ther is a great fungal diversity in fruits. Aspergillus sp., and Mucor sp., was found to be dominant on fruits. Hence, there is a need to explore possibilities of their control to prevent loss of product and injuries to human health.

\section{Acknowledgements:}

The authors are thankful to Dr. L. S. Ladke, Principal, Nilkanthrao Shinde Science and Arts College Bhadrawati, Dist - Chandrapur (MS)for providing laboratory facilities. The authors also thanks to Dr. A.A.Fulzele, Head, Department of Botany, Mohata Science College, Nagpur for his help to identify fruits infecting fungi.

\section{References:}

Adisa, V.A. (1993): Some extracellular enzymes associated with two tomato fruit spoilage molds. Mycopathologia, 91:101-108.

Akinyele, B.J. and Akinkunmi, O.(2012): Fungi associated with spoilage of berry and their reaction to electromagnetic field. Journal of Yeast and Fungal Research, Vol.3 (4) :49-57.

Alex Opoulos, C. J. (1960): Introductory Mycology, 2nd Edition, John Wiley and Sons, New York.

Al-Hindi, R.R., Al-Najada, A.R. and Mohamed, S.A.(2011) : Isolation and identification of some fruit spoilage fungi : screening of plant cell wall degrading enzymes. African Journal of Microbiology Research, Vol.5 (4):443-448.

Babu, H.B.N., Mahesh, P.A., Venkatesh, Y.P. (2008): A cross-sectional study on the prevalence of food allergy to eggplant (Solanum melangena L.) reveals female predominance Clin. Exp. Allergy, 38 : 1795-1802.

Bauri, N.C. (2007): Fungal spore, a potential source of occupational health hazard among the working of potato cold stores in West Bengal, India. World allergy congress (TM), Bangkok, Thailand.

Bessey, E. A. (1968): Morphology and Taxoonomy of Fungi The Blakistan Co., Philadelphia

Chatage, V.S. Bhale, U.N.(2010): Fungi associated with fruit rot disease of ivy gourd (Coccinia indica Wight and Arn) from Maharashtra,India. Bioinfolet 7: (3) : 242-243.

Churde, M.U., Deshmukh, V.R., Pachkhede, A.U. (2011): Vegetable infecting fungi from Amravati Market (M.S.)India.Bioinfolet 8(4):384386.

Dandge, V.s. (1998): Taxonomical and physiological studies of some fungi causing diseases to fruits and vegetables. Ph.D.Thesis, SGB Amravati University, Amravati., M.S.,India

M. J Britz, Z.H., Steenkamp, E.T., Coutinho, T. A., Wingfield, B.D., Marasas, W.F.O., Wingfield,. (2002): Two new species of Fusarium section Liseola associated with mango malformation. Mycologia. 94: 722-730.

Marasas, W.F.O., Ploetz, R. C., Wingfield, M. J., Wingfield, B.D., Steenkamp, E.T.(2006): Mango malformation disease and the associated Fusarium species. Phytopathol. 96:667-672.

Mordue, J.E.M. (1980): Descriptions of fungi and bacteria, 68 Sheet 678 .

Morsy, S.M., Drgham, E.A. and Mohammed, G.M. (2009): Effect of garlic and onion extracts or their intercropping on suppressing damping off and powdery mildew diseases and growth characteristics of cucumber. Egyptian Journal of Phytopathology, 37(1): 45-46

Morton, J. (1987): Mango In: Fruits of warm climates, Julia F. Morton, Miami, FL. pp. 221239.

Okereke, V.C.,Godwin-Egein, M.I., Arinze, A.E.(2010): Assessment of postharvest Rot of mango at Different stages of market in port Harcourt, Nigeria.Int.J.Curr.Res, 11 : 006-010.

Ploetz, R.C., David, B., Schaffer (1996). A reexamination of mango decline in Florida plant, Dis., 80(6):664-668.

Rawal, R.D. (1998): Management of fungal disease in tropical fruits. In: Tropical fruits in Asia: diversity, Maintenance, Conservation and Use (Eds) Richard E. Litz. The Mango; Botany, Production and Uses Sec Edn 2009, pp: 259.

Sarvottam, I.D., Sanjay., R., Baby, U.I., Mandal, A.K.A. (2009): Molecular characterization of pestalotiopsis spp. associated with tea (Camellia sinensis) in Southern India using RAPD and ISSR markers. Ind.J.Biotechnol.,18:337-383.

Savant, N.V., Raut, S.P. (2000): Studies on Symptomatology of dieback of mangostone grafts. Acta Hort. (ISHS), S 09 : 823-832.

Sekhon, A.S. and Shivapuri, T.N. (1971): Fungi of certain stores vegetable seeds in relation to pre and post emergence effect. Mycopathologia, Vol. 43 p. 211-215

Sharma, I. (1993): A note on population dynamics and etiology of dieback of mango in Himachal Pradesh, New Agriculture 2(2):229230.

Shikha Agblor and Doug Waterer (2001): 
Cabbage post harvest handling and storage.Agri-food Innovation Fund,Post harvest specialist programme, Department of Plant Sciences, University of Saskatchewan, Canada.

Sinha, S. (1946): On decay of certain fruits in storage. Proceedings plant sci .24:198-205.

Tournas, V.H. (2005) : Spoilage of vegetable crops by bacteria and fungi and related health hazards, Critical reviews in Microbiology Vol.87, pp: 33-44.

Vashishta, B. R. and Sinha, A. K. (2002): Fungi S. Chand and Company Ltd, New Delhi

Waller, J.M. (1992): Colletotrichum Disease of Perennial and other cash crops. In: Colletotrichum: Biology, Pathology and Control, Bailey, JA and MJ Jeger (Eds). CAB International Wallingford, U.K., pp: 167-186. 